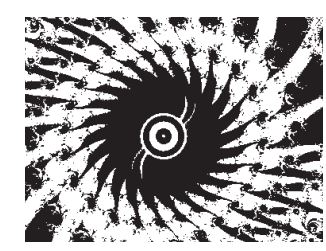

\title{
OBRASCI DRUŠTVENOSTI I PERCEPCIJA IZVORA NEFORMALNE SOCIJALNE PODRŠKE U HRVATSKOJ
}

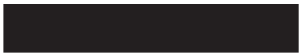

Ivana DOBROTIĆ, Maja LAKLIJA

Pravni fakultet, Zagreb

$$
\begin{aligned}
\text { UDK: } & 364.014(497.5) \\
& 364.044 .64(497.5) \\
& 364.046 .2(497.5)
\end{aligned}
$$

Izvorni znanstveni rad

Primlieno: 14. 9. 2010.

Ovaj rad nastao je u okviru rada na projektu Pokazatelii socijalne kohezije i razvoi hrvatskoga socijalnog -0661686-1432), provođenog uz potporu Ministarstva znanosti, obrazovanja i sporta Republike Hrvatske. Zahvaljujemo UNDP-u Hrvatska na ustuplienoi bazi podataka istraživanja kvalitete života u Hrvatskoj. modela 066 -

Surha je rada dati uvid u prirodu socijalnih veza te percepciju izvora neformalne socijalne podrške u Hrvatskoj s obzirom na sociodemografska obiliežja ispitanika. Izvor podataka bilo je Europsko istraživanje kvalitete života, koje je za Hrvatsku proveo UNDP Hrvatska. Analiza je provedena na uzorku od 8114 punoljetnih ispitanika. Prilikom analize čimbenika učestalosti kontakta primijenjena je linearna regresijska analiza, a na percepciju izvora neformalne socijalne podrške hi-kvadrat test. Rezultati su uputili na učestale socijalne interakcije unutar sekundarne sfere društvenosti, dok se obiteli percipira kao primarni izvor neformalne socijalne podrške. Najvažnijim su se prediktorima učestalosti kontakata unutar sekundarne sfere društvenosti pokazali: spol, dob, život s partnerom, veličina kućanstva te naselja i visina dohotka. Nadalje, dok praktična podrška primarno počiva na obitelii, u slučaju potrebe za emocionalnom te financijskom podrškom ispitanici se uz obiteli obraćaju i prijateljima. Kod emocionalne podrške učestalija je i percepcija podrške susjeda, dok u slučaju potrebe za financijskom podrškom osobe najčešće percipiraju kako se nemaju komu obratiti.

Ključne riječi: društvenost, socijalne veze, socijalna podrška

\ Ivana Dobrotić, Pravni fakultet Sveučilišta u Zagrebu, Studiijki centar socijalnog rada, Nazorova 51, 10000 Zagreb, Hrvatska.

E-mail: ivana.dobrotic@pravo.hr 
Različiti procesi suvremenoga društva - kao što su globalizacija, konkurentnost, povećana mobilnost, povećana upotreba suvremenih tehnologija te demografske promjene - dovode do mijenjanja društvenih odnosa i stavljaju nove izazove pred pojedinca i društvo. Autori (Speer i sur., 2001.; Perren i sur., 2004.) upozoravaju na manjak socijalne integracije i socijalne podrške u suvremenom društvu, što vide kao posljedicu činjenice da ljudi češće ne žive $u$ istom susjedstvu kao njihove obitelji, kolege s posla ili prijatelji. Osiromašenjem socijalnih veza rezultira i nezaposlenost te općenito socijalna nesigurnost, čime su jače pogođene osobe nižega socioekonomskog statusa (Olagnero i sur., 2005.). Time dolazi do krize socijalne kohezije, bitan aspekt koje su upravo socijalna solidarnost, socijalne mreže i socijalni kapital. Naime, kohezivno društvo karakterizira visok stupanj socijalnih interakcija između i unutar zajednice te obitelji, a socijalna se kohezija na lokalnoj razini uspijeva zadržati kroz socijalizacijske procese i uzajamne mehanizme podrške (Kearns i Forrest, 2000.).

Polazeći od koncepta socijalnoga kapitala, na socijalne se veze ponajprije gleda kao na koristan izvor resursa za pojedinca i društvo (Lin, 2001.; Pichler i Wallace, 2009.). Naime, neformalne potporne mreže zasnovane na solidarnosti i emocionalnoj povezanosti čine dopunu institucionaliziranim službama te nose dio tereta pružanja neformalnih oblika pomoći i podrške (Žganec, 1995.; Wall i sur., 2001.). Time postaju važnim izvorom socijalnoga kapitala, posebice za ranjive skupine (Wall i sur., 2001.), na što upozorava i Böhnke (2008.), ističući kako se unutar lokalnih zajednica s razvijenim socijalnim kapitalom mnogi problemi preveniraju i rješavaju spontanom i dobrovoljnom suradnjom građana. Obiteljske i društvene veze važne su i za održavanje kvalitete života (Olagnero i sur., 2005.), pa su pojedinci sa slabijim socijalnim vezama podložniji brojnim zdravstvenim i socijalnim problemima (Speer i sur., 2001.). Studije naglašavaju važnost socijalnih veza i s aspekta zaštite mentalnoga zdravlja (Brissette i sur., 2000.; Walen i Lachman, 2000.; Speer i sur., 2001.; Böhnke, 2008.), prevencije marginalizacije te osiguravanja socijalne podrške (Kearns i Forrest, 2000.; Piselli, 2007.; Böhnke, 2008.).

Poznavanje postojećih socijalnih veza u zajednici / društvu od velike je važnosti, ponajprije za kreatore javnih politika. Upravo postojanje socijalnih veza upućuje na (ne)postojanje mehanizama zadovoljavanja potreba te pružanja podrške, kao i na opseg socijalnog kapitala. Lakey i Cohen (2000.) naglašavaju kako uspješne intervencije zahtijevaju razumijevanje izvora socijalne podrške, a neefikasnost intervencija vide kao posljedicu zanemarivanja toga istraživačkog područja. 
DRUŠ. ISTRAŽ. ZAGREB GOD. 21 (2012), BR. 1 (115), STR. 39-58

DOBROTIĆ, I. LAKLIJA, M.: OBRASCI...
Socijalne veze te njihova efektivnost $\mathrm{u}$ obliku socijalne podrške posebice su važni s aspekta socijalne politike, jer mogu biti važan izvor resursa te dopuna postojećim programima. Tako Olagnero i sur. (2005.) međugeneracijske veze i srodničku solidarnost vide korisnim izvorom skrbi za djecu i starije osobe. Važne su i veze među članovima obitelji i s prijateljima, susjedima te drugim bliskim osobama. ${ }^{1}$

Radi se o dinamičnom području, koje treba kontinuirano analizirati i u skladu s dobivenim spoznajama kreirati, prilagođavati te na njega primijeniti mjere i programe. Naime, studije upozoravaju na promjene socijalnih veza - bilo tijekom životnoga vijeka bilo kao posljedicu društvenih promjena. Olagnero i sur. (2005.) na primjeru Irske i Italije pokazuju kako promjene izazivaju učinkovitost tradicionalne socijalne države, koja se temelji na obitelji, jer se manje može počivati na pretpostavci da majke igraju punu ulogu osobe koja skrbi.

Priroda socijalnih veza te potpornih aktivnosti ovisi i o društvenom kontekstu. Istraživanja (Paugam i Russell, 2000.; Reher, 2004.; Pichler i Wallace, 2007.; Böhnke, 2008.) pokazuju kako su one različita intenziteta te različito dolaze do izražaja u različitim društvima. Nadalje, Lin i sur. (2001.) ističu kako nejednakost pristupa socijalnom kapitalu određuju i osobne značajke pojedinca, pa je $\mathrm{u}$ temelju teorije socijalnoga kapitala ocrtavanje obrazaca te čimbenika nejednake distribucije resursa. To upućuje na potrebe istraživanja obrazaca društvenosti i socijalne podrške $u$ različitim sredinama te skupinama.

Stoga je svrha rada dati uvid u opseg i prirodu socijalnih veza, kao i u percepciju postojećih izvora neformalne socijalne podrške u Hrvatskoj s obzirom na demografska i socioekonomska obilježja ispitanika.

\section{SOCIJALNE VEZE I SOCIJALNA PODRŠKA}

Socijalne veze podrazumijevaju niz međusobnih interakcija među koje se ubrajaju i socijalne mreže te socijalna podrška. Socijalne su mreže objektivni pokazatelji socijalnih odnosa koji govore o tome s kim pojedinac održava veze, ali ne i o kvaliteti odnosa, koja se najčešće procjenjuje konceptom socijalne podrške (Antonucci, 2001.). Antonucci (1985.) tvrdi kako socijalne mreže tvore strukturu kroz koju se socijalna podrška razmjenjuje; dok socijalna podrška podrazumijeva potporne društvene interakcije.

Socijalne mreže čine polje formalnih i neformalnih odnosa pojedinca, unutar kojih se omogućuje razmjena usluga, informacija i drugih dobara (Mandič i Hlebec, 2005.). Predstavljaju izvor formalnoga i neformalnoga socijalnog kapitala, što se vidi iz definicije Lin (2001.), koja socijalni kapital određuje kao resurs sadržan u socijalnim strukturama koji se 
DRUŠ. ISTRAŽ. ZAGREB GOD. 21 (2012), BR. 1 (115)

STR. 39-58

DOBROTIĆ, I., LAKLIJA, M.: mobilizira prema potrebi. Literatura koja se temelji na teorijama socijalnih mreža zasniva se na neformalnom socijalnom kapitalu (različitosti i intenzitetu neformalnih socijalnih mreža koje počivaju na srodstvu, prijateljstvu, susjedstvu ...), dok se studije demokracije i civilnoga društva temelje na formalnom socijalnom kapitalu (sudjelovanje $\mathrm{u}$ organizacijama civilnoga društva) (Pichler i Wallace, 2007.).

Socijalne se veze često procjenjuju učestalošću socijalnih interakcija (Antonucci, 2001.) i najčešće analiziraju kroz tri sfere. Primarna sfera zahvaća najbliže obiteljske i druge odnose unutar kućanstva, sekundarna odnose sa susjedima, susrete s prijateljima te rođacima izvan kućanstva, dok se tercijarna sfera odnosi na sudjelovanje $\mathrm{u}$ organiziranim aktivnostima i udruženjima (Paugam i Russell, 2000.). Važno je naglasiti kako one nisu kumulativne, pa u raznim društvima razne sfere dolaze do izražaja. Böhnke (2008.) upozorava na važnost obiteljske kohezivnosti i međugeneracijske solidarnosti u mediteranskim i istočnoeuropskim zemljama te na orijentiranost na prijatelje i organizirana udruženja u skandinavskim zemljama. ${ }^{2}$ Stoga je te tri sfere važno izučavati odvojeno.

Pichler i Wallace (2009.) ističu kako je uz gustoću socijalnih mreža važna i učestalost te intenzitet interakcija, o čemu ovisi potencijal pojedinca da ih aktivira te pristupi resursima. Kao mogući resurs za jačanje socijalne kohezije važne su snažne veze, ali i one manjeg intenziteta (Granovetter, 1983.). Štoviše, Pahl i Spencer (1997.) smatraju da su prijateljske mreže nedovoljno istražen te podcijenjen izvor socijalne kohezije $u$ suvremenom društvu, gdje slabe prijateljske veze dobivaju na važnosti. Isto tako, specifičnost prijateljske mreže u njezinu slobodnom odabiru važna je cijeloga života, nije lokalizirana i naglasak je na kvaliteti odnosa.

Socijalna mreža pojedinca važan je aspekt socijalne podrške (Agneessens i sur., 2006.), jer je socijalna podrška često određena veličinom, strukturom i karakteristikama socijalne mreže pojedinca (Brownell i Shumaker, 1985.). Literatura daje niz definicija socijalne podrške (Cobb, 1976.; Thoits, 1982.; Antonucci, 1985.; Petz i sur., 1992.). Ono što je većini zajedničko jest da socijalna podrška podrazumijeva dostupnost resursa u socijalnoj okolini koji pojedincu pružaju podršku u svakodnevnom životu te kriznim situacijama i time pridonose njegovoj dobrobiti. Na socijalnu se podršku gleda kao na multidimenzionalan koncept, pa razlikujemo razne oblike i izvore podrške. Broj pojedinaca koji su potencijalan izvor podrške tek je dio kompleksnosti (Agneessens i sur., 2006.), dok je uloga odnosa ključna za tipiziranje izvora pojedine dimenzije podrške (Agneessens i sur., 2002.).

Literatura (Antonucci, 1985.; Thoits, 1982.; Wellman i Wortley, 1989.; Sarafino, 2002.) nudi razne kategorizacije socijalne 
DRUŠ. ISTRAŽ. ZAGREB GOD. 21 (2012), BR. 1 (115) STR. 39-58

DOBROTIĆ, I., LAKLIJA, M. OBRASCI.. podrške, gdje su najčešće dimenzije emocionalna, instrumentalna i savjetodavna podrška. Emocionalna podrška definira se kao izraz moralne potpore, razumijevanja osjećaja i promišljanja, empatije te brige za drugu osobu od pojedinca i/ili okoline. Materijalna ili instrumentalna podrška pruža osobi izravnu potporu $\mathrm{u}$ obliku usluga i materijalnih dobara (pomoć u kućanstvu, skrb za djecu, materijalna pomoć ...). Savjetodavna podrška uključuje davanje savjeta, uputa, prijedloga ili povratnih informacija o djelovanju pojedinca. ${ }^{3}$

\section{RANIJA ISTRAŽIVANJA}

Dosadašnje se analize usmjeravaju na obilježja ne(postojanja) socijalnih veza, veličine, strukture i intenziteta socijalnih mreža te socijalne podrške, kao i na posljedice (ne)postojanja socijalnih veza / mreža i socijalne podrške na dobrobit pojedinaca. S obzirom na cilj rada, izdvajamo rezultate istraživanja o čimbenicima socijalnih veza i raznolikosti potpornih mreža.

Uz pravila u pojedinom društvu / sredini, na postojanje te obilježja socijalnih veza / mreža ponajprije utječu individualne značajke. Tako studije upućuju na raznolikost socijalnih mreža pojedinaca s obzirom na obilježja spola, dobi, partnerskoga statusa te veličine i strukture obitelji (Antonucci, 1985., 2001.; Moore, 1990.; Albeck i Kayder, 2002.; Antonucci i sur., 2002.; Novak i sur., 2004.; Perren i sur., 2004.). Karakteristike socijalnih veza određuju i socioekonomska obilježja, ponajprije obrazovna razina pojedinaca, materijalni status te zaposlenje (Antonucci, 2001.; Paugam i Russel, 2000.; Sarafino, 2002.; Novak i sur., 2004.; Piselli, 2007.; Pichler i Wallace, 2009.). Analize usmjerene na ruralno-urbane razlike $\mathrm{u}$ socijalnim vezama pokazuju jednaku uključenost u potporne socijalne mreže, ali i na razlike u sadržaju odnosa, jer stanovnici gradova često pripadaju širim mrežama (Fischer, 1982.).

Uz pravila u danom društvu, te razlike među urbanim i ruralnim sredinama (Agneessens i sur., 2006.) i socijalnu podršku određuju sociodemografska obilježja pojedinca, ali i domena života iz koje podrška potječe (npr. posao, obitelj, škola ...) (Brownell i Shumaker, 1985.). Istraživanja pokazuju kako pojedinci uvelike počivaju na neformalnim izvorima socijalne podrške (Olagnero i sur., 2005.), gdje obitelj ima najvažniju potpornu ulogu, ali i da razne skupine stanovništva nemaju jednak pristup podršci (Novak, 2004.; Wall i sur., 2001.). Dostupnost socijalne podrške određena je sociodemografskim značajkama pojedinca (Fischer, 1982.; Vaux, 1985.; Koropeckyj-Cox, 1998.; Sugisawa i sur., 2002.; Novak, 2004.; Perren i sur., 2004.), pri čemu izvori socijalne podrške variraju tijekom životnoga ciklusa, a često i kao posljedica određenoga događaja, kao što je npr. rastava (Demo i Fine, 2010.). Glede 
DRUŠ. ISTRAŽ. ZAGREB GOD. 21 (2012), BR. 1 (115),

STR. 39-58

DOBROTIĆ, I., LAKLIJA, M.: OBRASĆL. izvora podrške, analize (Wellman i Wortley, 1989.; Schweizer i sur., 1998.) pokazuju kako su bliski srodnici češće izvor emocionalne i instrumentalne podrške, dok su prijatelji važniji za druženje. Također, instrumentalnu podršku često pružaju i susjedi (Schweizer i sur., 1998.; Novak, 2004.).

Dok se istraživački nalazi slažu u tome da je obitelj dominantan izvor društvenosti i socijalne podrške (npr. Wall i sur., 2001.; Novak, 2004.; Saraceno i sur., 2005.; Olagnero i sur., 2005.), potpuni konsenzus glede čimbenika socijalnih veza te strukture potpornih mreža ne postoji. Naime, istraživanja često daju različite rezultate glede istih sociodemografskih čimbenika, koji se rabe u objašnjavanju obrazaca društvenosti i raznolikosti potpornih mreža. To dijelom objašnjavamo različitim sociokulturnim okruženjem, ali i problemima metodološke naravi, što se ponajprije odnosi na nereprezentativne uzorke i primjenu različitih mjernih instrumenata.

Usmjerimo li se na Hrvatsku, istraživanja su na tom području rijetka te dominantno usmjerena na socijalnu podršku specifičnih skupina u pojedinim aspektima, kao što su nezaposlenost, roditeljstvo, skrb za djecu, starije osobe te osobe s invaliditetom i sl. (Sladović Franz i Mujkanović, 2003.; Kregar, 2004.; Matković, 2006.; Raboteg-Šarić i Pećnik, 2006.; Leutar i sur., 2007., 2008.; Podgorelec i Klempić, 2007.).

\section{CILJEVI RADA}

Kako obilježja društvenosti i neformalne socijalne podrške ovise o situacijskim karakteristikama te variraju od zemlje do zemlje, namjera je rada dati doprinos izučavanju obilježja socijalnih veza te obrazaca neformalne socijalne podrške u Hrvatskoj.

Primarna je namjera utvrditi učestalost neposrednih kontakata s rođacima izvan kućanstva, susjedima i prijateljima te upozoriti na čimbenike koji pridonose učestalosti kontakata. Polazeći od postavke Paugama i Russella (2000.) o trorazinskoj prirodi socijalnih veza, analiza se usmjerava na sekundarnu razinu društvenosti.

Kako je važan indikator jačine neformalnoga socijalnog kapitala socijalna podrška operacionalizirana kroz uključenost osobe u neformalne potporne mreže (Pichler i Wallace, 2007.), sljedeća je namjera upozoriti na percepciju dostupnosti neformalne socijalne podrške te razlikuju li se izvori podrške s obzirom na njezin oblik i osobne značajke ispitanika. Na tragu ranijih istraživanja (Antonucci, 1985.; Thoits, 1982., Wellman i Wortley, 1989.; Sarafino, 2002.; Taylor i sur., 2003.) i činjenicu da pojedinci počivaju na različitim značajnim drugima za različite izvore podrške (Agneessens i sur., 2002.), zasebno razmatramo percepciju emocionalne, savjetodavne $\mathrm{i}$ instrumentalne podrške. 


\section{METODOLOGIJA}

Analiza se temelji na podacima UNDP-ova anketnog istraživanja kvalitete života u Hrvatskoj, provedenog 2006. godine (UNDP, 2007.), gdje je među ciljevima bio i ovaj: ispitati i obrasce podrške i društvenosti. Uzorak je konstruiran kao četvoroetapni probabilistički uzorak i obuhvaća 8400 ispitanika starijih od 16 godina. Provedena je neproporcionalna stratifikacija po županijama kroz alokaciju 400 planiranih ispitanika po županiji. Odabir lokacija anketiranja (druga etapa) proveden je kao slučajan izbor 50 naselja, gdje je vjerojatnost izbora u uzorak bila proporcionalna broju stanovnika planiranoga ciljnog segmenta stanovništva. Odabir domaćinstva proveden je random-walk metodom, a unutar domaćinstva u četvrtoj je etapi proveden slučajni odabir jednog ispitanika metodom zadnjeg rođendana. Za potrebe procjene populacije građana Hrvatske starijih od 16 godina podaci su uteženi s obzirom na veličinu županije i poststratifikacijski kalibrirani na podatke o populaciji iz Popisa stanovništva 2001. usklađenima s projekcijom promjena dobne strukture do 2006. prema varijablama spola, dobi i obrazovanja. Ova je analiza provedena na uzorku ispitanika starijih od 18 godina $(\mathrm{N}=8114)$, od čega 53,1\% ženskih i 46,9\% muških ispitanika. Prosječna je dob 47 godina, a $60,9 \%$ ispitanika živi s partnerom. Njih 13,1\% živi u samačkom kućanstvu. Većina ima srednju stručnu spremu $(49,1 \%)$, višu / visoku stručnu spremu ima $12,5 \%$, a najmanje završeno osnovnoškolsko obrazovanje $37,9 \%$ osoba. Zaposleno je $40,7 \%$ ispitanika, dok je $14 \%$ nezaposleno, 30,4\% u mirovini / nesposobno za rad, 7,8\% primarno obavlja kućanske poslove, a 7,1\% je na školovanju.

Sekundarna razina društvenosti operacionalizirana je kroz čestice: osobni socijalni kontakti izvan vlastita kućanstva s užim članovima obitelji (roditelji / djeca) te susjedima / prijateljima. Učestalost kontakta procjenjivana je na skali od šest stupnjeva ( 1 - rjeđe, 2 - nekoliko puta u godini, 3 - jednom / dvaput na mjesec, 4 - najmanje jednom na tjedan, 5 - svaki / skoro svaki dan; 6 - češće od jednom u danu). ${ }^{4}$

Emocionalna podrška operacionalizirana je kroz navođenje osoba koje su najčešći izvor podrške u situacijama kada se osjećamo bezvoljno i trebamo nekoga za razgovor; savjetodavna podrška kroz navođenje osoba koje su najčešći izvor podrške pri davanju savjeta u vezi s ozbiljnim osobnim / obiteljskim problemima, a instrumentalna podrška kroz navođenje osoba koje su najčešći izvor praktične (pomoć u kući u slučaju bolesti) te materijalne pomoći (ako hitno trebamo 500€). Wethington i Kessler (1986.) naglašavaju da je u prilagodbi na stresne situacije percepcija socijalne podrške važnija od primljene podrške. Također, Agneessens i sur. (2006.) ističu kako su izvori potencijalne podrške bolja mjera od stvarno primlje- 
DRUŠ. ISTRAŽ. ZAGREB GOD. 21 (2012), BR. 1 (115)

STR. 39-58

DOBROTIĆ, I., LAKLIJA, M.: ne podrške, jer drugi slučaj podrazumijeva postojanje stvarne potrebe.

Prihvaćajući tezu o nejednakosti pristupa socijalnom kapitalu, na tragu ranijih istraživanja kao prediktore $u$ analizu uvodimo sljedeće individualne značajke ispitanika: spol ( 0 - muškarci, 1 - žene), dob, obrazovnu razinu (1 - najmanje završena osnovna škola, 2 - završena srednja škola, 3 - završeno više / visoko obrazovanje), partnerski status (1 - živi s partnerom, 2 - ne živi s partnerom), prisutnost djece; broj članova kućanstva; prihode kućanstva (objektivni pokazatelj mjesečnih primanja), aktivnost ispitanika ( 1 - zaposleni, 2 - nezaposleni, 3 - umirovljeni / nesposobni za rad, 4 - primarno obavljaju kućanske poslove, 5 - na školovanju) te područje stanovanja (ruralno / urbano).

S obzirom na karakteristike kriterijskih varijabli na kojima se procjenjivala učestalost kontakata te primarnu namjeru rada, prilikom analize čimbenika učestalosti kontakta primijenjena je linearna regresijska analiza (OLS), pri čemu se analiza izvodila za svaku kriterijsku varijablu zasebno. Kako kod analize percepcije izvora socijalne podrške namjera nije bila ispitati čimbenike izvora socijalne podrške nego prisutnost razlika među skupinama, u daljnjoj je analizi primijenjen hi-kvadrat test.

\section{REZULTATI I RASPRAVA}

\section{Čimbenici sekundarne razine društvenosti}

Dok je razina formalnoga socijalnog kapitala niska u Hrvatskoj (tek oko 5\% ispitanika sudjeluje u radu dobrovoljnih organizacija), posebice u usporedbi s drugim europskim zemljama, ${ }^{5}$ obrazac ponašanja vrlo je sličan kod neformalnog socijalnoga kapitala. Naime, analiza pokazuje učestalost neposrednih kontakata s članovima uže i šire društvene sredine. Tako $88,1 \%$ ispitanika učestalo neposredno kontaktira s djecom te njih $72,7 \%$ s roditeljima koji žive izvan kućanstva. Učestalost neposrednih kontakata s prijateljima / susjedima također je evidentna te $93,2 \%$ ispitanika učestalo kontaktira s prijateljima / susjedima. ${ }^{6}$ Rezultati pokazuju obrasce sekundarne sfere društvenosti u Hrvatskoj slične onima u drugim europskim zemljama, gdje članovi obitelji također imaju važnu ulogu (Saraceno i sur., 2005.).

Prediktori učestalosti neposrednih kontakata s članovima obitelji (Tablica 1 ) objašnjavaju $25,4 \%$ varijance kod kontakata s djecom te 19\% varijance kod kontakata s roditeljima. Na obje su se kriterijske varijable statistički značajnima pokazali: spol, dob, partnerski status, veličina kućanstva te naselja i visina dohotka. Dok žene i osobe koje žive s partnerom te 
DRUŠ. ISTRAŽ. ZAGREB GOD. 21 (2012), BR. 1 (115) STR. 39-58

DOBROTIĆ, I., LAKLIJA, M. OBRASCI..

(1) TABLICA 1 Prediktori sekundarne razine društvenosti osobe višega obrazovnog statusa učestalije kontaktiraju s djecom, muškarci te osobe koje ne žive s partnerom učestalije kontaktiraju s roditeljima. Život u većoj sredini pridonosi učestalijim kontaktima s djecom te kontaktima slabijeg intenziteta s roditeljima. Učestalijim kontaktima s članovima obitelji pridonosi viši dohodovni status i život u višečlanim obiteljima, dok oni slabe s višom životnom dobi pojedinca. Usporedimo li ih sa zaposlenim osobama, učestalost kontakata s djecom manja je kod umirovljenika / nesposobnih za rad, a s roditeljima kod osoba koje obavljaju kućanske poslove.

\begin{tabular}{|c|c|c|c|c|c|c|}
\hline \multirow[t]{2}{*}{ Učestalost neposrednih kontakata s: } & \multicolumn{2}{|c|}{ djecom } & \multicolumn{2}{|c|}{ roditeljima } & \multicolumn{2}{|c|}{$\begin{array}{c}\text { prijateljima / } \\
\text { susjedima }\end{array}$} \\
\hline & B & Beta & B & Beta & B & Beta \\
\hline A & 4,555 & & 2,930 & & 5,004 & \\
\hline Spol & $0,161^{*}$ & 0,063 & $-0,222^{*}$ & $-0,071$ & $-0,102^{*}$ & $-0,054$ \\
\hline Dob & $-0,013^{*}$ & $-0,154$ & $-0,018^{*}$ & $-0,138$ & $-0,008^{*}$ & $-0,145$ \\
\hline Partnerski status & $-0,099 * *$ & $-0,033$ & $0,972^{*}$ & 0,300 & $0,165^{*}$ & 0,085 \\
\hline Broj članova kućanstva & $0,221^{*}$ & 0,283 & $0,163^{*}$ & 0,160 & $0,020^{*}$ & 0,034 \\
\hline Veličina naselja & $0,111^{*}$ & 0,107 & $-0,120^{*}$ & $-0,095$ & $-0,108^{*}$ & $-0,139$ \\
\hline Obrazovana razina & $0,089^{*}$ & 0,047 & 0,036 & 0,014 & $-0,008$ & $-0,005$ \\
\hline Visina dohotka & $0,029^{*}$ & 0,074 & $0,060^{*}$ & 0,117 & $0,015^{*}$ & 0,051 \\
\hline Nezaposlenost $^{* * *}$ & $-0,073$ & $-0,019$ & 0,033 & 0,008 & 0,053 & 0,019 \\
\hline Umirovljenje/ nesposobnost za $\operatorname{rad}^{* * *}$ & $-0,142^{*}$ & $-0,054$ & 0,103 & 0,019 & $0,128^{*}$ & 0,062 \\
\hline Kućanstvo ${ }^{* * *}$ & $-0,085$ & $-0,020$ & $-0,318^{*}$ & $-0,049$ & $0,105^{* *}$ & 0,030 \\
\hline Školovanje ${ }^{* * *}$ & - & - & $-0,081$ & $-0,016$ & $0,310^{*}$ & 0,084 \\
\hline $\mathrm{R}^{2}$ & \multicolumn{2}{|c|}{0,254} & \multicolumn{2}{|c|}{0,190} & \multicolumn{2}{|c|}{0,065} \\
\hline broj slučajeva & \multicolumn{2}{|c|}{5197} & \multicolumn{2}{|c|}{4558} & \multicolumn{2}{|c|}{7894} \\
\hline
\end{tabular}

Napomene: ${ }^{*} \mathrm{p}<0,01 ;{ }^{* *} \mathrm{p}<0,05 ;{ }^{* * *}$ referentna skupina "zaposlenost"; spol ( $0=$ muškarci, $1=$ žene); partnerski status ( 1 - živi s partnerom, 2 - ne živi s partnerom)

Prediktori učestalosti kontakata s prijateljima / susjedima objašnjavaju 6,5\% varijance. Muškarci i osobe koje ne žive s partnerom učestalije kontaktiraju s prijateljima / susjedima. Starija životna dob i život u većem naselju pridonose slabijem intenzitetu kontakata s prijateljima / susjedima. S druge strane intenzivnijim kontaktima s prijateljima / susjedima pridonose viši prihodi i život u višečlanom kućanstvu. Također, umirovljenici, osobe koje obavljaju kućanske poslove te osobe na školovanju intenzivnije kontaktiraju s prijateljima / susjedima.

Rezultati potvrđuju ranija istraživanja, ponajprije istraživanja koja upućuju na smanjivanje učestalosti kontakata s dobi (Kearns i Forrest, 2000.; Perren i sur., 2004.), te rašireniju percepciju izoliranosti među osobama nižega socioekonomskog statusa (Novak i sur., 2004.). Činjenicu da osobe višega dohodovnog statusa ostvaruju učestalije kontakte Fischer (1982.) pripisuje posjedovanju više resursa potrebnih za održavanje socijalnih veza. Nadalje, učestalije kontakte kod višečlanih obi- 
DRUŠ. ISTRAŽ. ZAGREB GOD. 21 (2012), BR. 1 (115)

STR. 39-58

DOBROTIĆ, I., LAKLIJA, M.: OBRASCI.. telji možemo povezati s činjenicom da na socijalne veze pozitivno utječe partnerski status i prisutnost djece (Albeck i Kayder, 2002.; Novak i sur., 2004.), pa te osobe ostvaruju kontakte sa širim krugom ljudi.

S aspekta aktivnosti, zaposleni ostvaruju manje intenzivne kontakte s prijateljima / susjedima. I tu Hrvatska pokazuje trendove slične drugim europskim zemljama, gdje se manja intenzivnost kontakata pripisuje činjenici da oni raspolažu s manje slobodna vremena za druženje (Saraceno i sur., 2005.). Zanimljivo je upozoriti na to kako urbaniziranija naselja karakteriziraju učestaliji kontakti s djecom, a ruralnija učestalija intenzivnost kontakta s roditeljima i susjedima / prijateljima. To može imati implikacija ponajprije na starije osobe u urbanim naseljima, koje općenito karakterizira manja učestalost kontakata, posebice u slučaju potrebe za podrškom. To dodatno zabrinjava uzmemo li u obzir tvrdnju Perrena i sur. (2004.) kako su za starije osobe od osobita značenja lokalno utemeljene socijalne veze, jer više vremena provode $u$ okolini doma, pa su susjedi često izvor socijalne integracije.

\section{Percepcija izvora socijalne podrške}

Analiza percepcije izvora socijalne podrške (Tablica 2) pokazuje kako članovi obitelji / partner predstavljaju primarni izvor socijalne podrške, što potvrđuje ranija istraživanja (Wall i sur., 2001.; Novak, 2005.; Agneessens i sur., 2006.), kao i da u Hrvatskoj prevladavaju obrasci ponašanja slični onima u drugim europskim zemljama (Saraceno i sur., 2005.). Dok praktična podrška primarno počiva na obitelji, u slučaju potrebe za emocionalnom te financijskom podrškom ispitanici se uz obitelj češće obraćaju prijateljima. Kod emocionalne podrške uče-

(1) TABLICA 2

Percepcija socijalne podrške prema izvoru i vrsti (\%) stalija je i percepcija podrške susjeda, dok kod financijske podrške osobe najčešće smatraju kako se nemaju komu obratiti. Kolege s posla rijetko se percipiraju kao izvor socijalne podrške.

\begin{tabular}{lcccc}
\hline Podrška: & praktična & savjetodavna & emocionalna & financijska \\
\hline Član obitelji / partner & 89,5 & 68,9 & 57,3 & 53,5 \\
Kolega s posla & 0,2 & 1,1 & 1,0 & 1,6 \\
Prijatelji & 4,0 & 21,1 & 30,6 & 20,1 \\
Susjed & 3,9 & 3,8 & 6,9 & 3,1 \\
Netko drugi & 0,7 & 1,8 & 1,2 & 5,4 \\
Nitko & 1,3 & 2,8 & 2,5 & 13,4 \\
Ne znam & 0,4 & 0,6 & 0,4 & 3,0 \\
\hline
\end{tabular}

Dominantnu savjetodavnu i emocionalnu podršku obitelji / partnera, kao i da je obitelj / partner dominantan izvor podrške u slučaju bolesti, ali ne i potrebe za financijskom podrškom, pokazuju ranija istraživanja (Wellman i Wortley, 1989.; 
DRUŠ. ISTRAŽ. ZAGREB GOD. 21 (2012), BR. 1 (115) STR. $39-58$

DOBROTIĆ, I., LAKLIJA, M. OBRASCI..
(1) TABLICA 3

Percepcija izvora savjetodavne podrške gnero i sur., 2005.). Ipak, iako rjeđe, i u slučaju potrebe za financijskom podrškom primarno se obraća obitelji. Agneessens i sur. (2006.) pokazuju kako se u pravilu radi o bliskim rođacima, što je razumljivo, jer se s partnerom najčešće dijele resursi. Hlebec i Kogovšek (2003.) također tvrde da emocionalna podrška najčešće dolazi od članova obitelji i prijatelja.

Kako u slučaju potrebe za praktičnom podrškom ispitanici primarnim izvorom podrške dominantno smatraju članove obitelji / partnera (u gotovo $90 \%$ slučajeva), na toj varijabli nisu rađene dodatne analize, nego je daljnja analiza usmjerena na razlike $u$ percepciji izvora savjetodavne, emocionalne $\mathrm{i}$ financijske podrške. Takvi su nalazi na tragu teze Hlebec i Kogovšek (2003.) kako je obitelj češće izvor zahtjevnije i dugotrajnije podrške (npr. kod duže bolesti), dok su u slučaju instrumentalne podrške susjedi češće izvor povremene pomoći.

\begin{tabular}{|c|c|c|c|c|c|c|c|c|c|c|c|c|c|}
\hline \multirow[b]{2}{*}{ Prediktori } & \multicolumn{2}{|c|}{$\begin{array}{c}\text { Član obitelji / } \\
\text { partner }\end{array}$} & \multicolumn{2}{|c|}{$\begin{array}{l}\text { Kolega } \\
\text { s posla }\end{array}$} & \multicolumn{2}{|c|}{ Prijatelj } & \multicolumn{2}{|c|}{ Susjed } & \multicolumn{2}{|c|}{ Drugi } & \multicolumn{2}{|c|}{ Nitko } & \multirow[b]{2}{*}{$\chi^{2}$} \\
\hline & $\mathrm{N}$ & $\%$ & $\mathrm{~N}$ & $\%$ & $\mathrm{~N}$ & $\%$ & $\mathrm{~N}$ & $\%$ & $\mathrm{~N}$ & $\%$ & $\mathrm{~N}$ & $\%$ & \\
\hline \multicolumn{14}{|l|}{ spol } \\
\hline$\underset{\sim}{M}$ & 2498 & 66,2 & 53 & 1,4 & 888 & 23,5 & 110 & 2,9 & 65 & 1,7 & 157 & 4,2 & \multirow[t]{2}{*}{$95,748^{*}$} \\
\hline Ž & 3059 & 71,9 & 37 & 0,9 & 818 & 19,2 & 195 & 4,6 & 78 & 1,8 & 66 & 1,6 & \\
\hline \multicolumn{14}{|c|}{ partnerski status } \\
\hline $\mathrm{Da}$ & 3763 & 76,9 & 61 & 1,2 & 773 & 15,8 & 99 & 2 & 80 & 1,6 & 116 & 2,4 & \multirow[t]{2}{*}{$394,279^{*}$} \\
\hline $\mathrm{Ne}$ & 1782 & 57,3 & 29 & 0,9 & 925 & 29,8 & 205 & 6,6 & 62 & 2,0 & 105 & 3,4 & \\
\hline \multicolumn{14}{|c|}{ prisutnost djece } \\
\hline $\mathrm{Da}$ & 4306 & 75 & 63 & 1,1 & 920 & 16 & 209 & 3,6 & 101 & 1,8 & 143 & 2,5 & \multirow[t]{2}{*}{$363,699^{*}$} \\
\hline $\mathrm{Ne}$ & 1252 & 54,9 & 27 & 1,2 & 786 & 34,4 & 96 & 4,2 & 41 & 1,8 & 80 & 3,5 & \\
\hline \multicolumn{14}{|c|}{ kućanstvo*** } \\
\hline 1 & 566 & 53,8 & 8 & 0,8 & 263 & 25 & 157 & 14,9 & 11 & 1 & 47 & 4,5 & \multirow[t]{2}{*}{$461,480^{* *}$} \\
\hline 2 & 4991 & 71,6 & 82 & 1,2 & 1443 & 20,7 & 148 & 2,1 & 132 & 1,9 & 175 & 2,5 & \\
\hline \multicolumn{14}{|c|}{ obrazovni status } \\
\hline OŠ & 2197 & 72,4 & 22 & 0,7 & 409 & 13,5 & 240 & 7,9 & 64 & 2,1 & 102 & 3,4 & \multirow[t]{3}{*}{$385,864^{*}$} \\
\hline SŠ & 2663 & 67,5 & 55 & 1,4 & 1012 & 25,6 & 59 & 1,5 & 57 & 1,4 & 101 & 2,6 & \\
\hline VSS & 675 & 66,9 & 13 & 1,3 & 276 & 27,4 & 5 & 0,5 & 22 & 2,2 & 18 & 1,8 & \\
\hline \multicolumn{14}{|l|}{ dob } \\
\hline $18-24$ & 569 & 58,1 & 6 & 0,6 & 376 & 38,4 & 7 & 0,7 & 9 & 0,9 & 13 & 1,3 & \multirow[t]{5}{*}{$661,817^{*}$} \\
\hline $25-34$ & 873 & 65,6 & 16 & 1,2 & 390 & 29,3 & 8 & 0,6 & 25 & 1,9 & 19 & 1,4 & \\
\hline $35-49$ & 1551 & 70,2 & 44 & 2 & 473 & 21,4 & 39 & 1,8 & 47 & 1,9 & 55 & 1,4 & \\
\hline $50-64$ & 1361 & 72,9 & 21 & 1,1 & 297 & 15,9 & 81 & 4,3 & 37 & 2 & 71 & 3,8 & \\
\hline $65+$ & 1202 & 73,5 & 3 & 0,2 & 170 & 10,4 & 170 & 10,4 & 25 & 1,5 & 65 & 4 & \\
\hline \multicolumn{14}{|c|}{ visina dohotka ${ }^{* * * *}$} \\
\hline 1 & 1012 & 63,2 & 13 & 0,8 & 274 & 17,1 & 204 & 12,7 & 31 & 1,9 & 68 & 4,2 & \multirow[t]{4}{*}{$529,371^{*}$} \\
\hline 2 & 1609 & 69,7 & 36 & 1,6 & 498 & 21,6 & 55 & 2,4 & 45 & 1,9 & 67 & 2,9 & \\
\hline 3 & 1619 & 73,8 & 28 & 1,3 & 436 & 19,9 & 26 & 1,2 & 53 & 2,4 & 33 & 1,5 & \\
\hline 4 & 1233 & 68,7 & 12 & 0,7 & 468 & 26,1 & 17 & 0,9 & 10 & 0,6 & 54 & 3 & \\
\hline \multicolumn{14}{|c|}{ veličina naselja $a^{* * * *}$} \\
\hline 1 & 2368 & 69,2 & 48 & 1,4 & 629 & 18,4 & 203 & 5,9 & 84 & 2,5 & 90 & 2,6 & \multirow[t]{4}{*}{$192,956^{*}$} \\
\hline 2 & 990 & 71,4 & 21 & 1,5 & 283 & 20,4 & 57 & 4,1 & 7 & 0,5 & 29 & 2,1 & \\
\hline 3 & 943 & 67,4 & 15 & 1,1 & 364 & 26 & 24 & 1,7 & 30 & 2,1 & 23 & 1,6 & \\
\hline 4 & 1257 & 69,1 & 6 & 0,3 & 430 & 23,7 & 21 & 1,2 & 23 & 1,3 & 81 & 4,5 & \\
\hline
\end{tabular}

Napomene: *p<0,05; **p<0,01; ${ }^{* * *} 1=$ samačko, $2=$ višečlano; ${ }^{* * *} 1=$ do 2000 kn; 2=2001-5000 kn; 3=5001$-10000 \mathrm{kn} ; 4=>10001 \mathrm{kn} ;{ }^{* * * *} 1=$ do 2000 stanovnika, $2=2001-10000$ stanovnika, 3=10001-100000 stanovnika, $4=>100001$ stanovnika 


\begin{tabular}{|c|c|c|c|c|c|c|c|c|c|c|c|c|c|}
\hline \multirow[b]{2}{*}{ Prediktori } & \multicolumn{2}{|c|}{$\begin{array}{r}\text { Član obitelji / } \\
\text { partner }\end{array}$} & \multicolumn{2}{|c|}{$\begin{array}{l}\text { Kolega } \\
\text { s posla }\end{array}$} & \multicolumn{2}{|c|}{ Prijatelj } & \multicolumn{2}{|c|}{ Susjed } & \multicolumn{2}{|c|}{ Drugi } & \multicolumn{2}{|c|}{ Nitko } & \multirow[b]{2}{*}{$\chi^{2}$} \\
\hline & $\frac{1}{N}$ & $\%$ & $\overline{\mathrm{N}}$ & $\%$ & $\mathrm{~N}$ & $\%$ & $\mathrm{~N}$ & $\%$ & $\mathrm{~N}$ & $\%$ & $\mathrm{~N}$ & $\%$ & \\
\hline \multicolumn{14}{|l|}{ spol } \\
\hline $\mathrm{M}$ & 2177 & 57,7 & 38 & 1 & 1190 & 31,5 & 184 & 4,9 & 51 & 1,4 & 133 & 3,5 & $72,981^{*}$ \\
\hline Ž & 2450 & 57,5 & 47 & 1,1 & 1277 & 30 & 371 & 8,7 & 45 & 1,1 & 71 & 1,7 & \\
\hline \multicolumn{14}{|c|}{ partnerski status } \\
\hline $\mathrm{Da}$ & 3281 & 67,1 & 61 & 1,2 & 1181 & 24,1 & 236 & 4,8 & 30 & 0,6 & 104 & 2,1 & $495,776^{*}$ \\
\hline $\mathrm{Ne}$ & 1335 & 42,8 & 23 & 0,7 & 1280 & 41,1 & 314 & 10,1 & 65 & 2,1 & 99 & 3,2 & \\
\hline \multicolumn{14}{|c|}{ prisutnost djece } \\
\hline $\mathrm{Da}$ & 3699 & 64,3 & 69 & 1,2 & 1363 & 23,7 & 432 & 7,5 & 45 & 0,8 & 141 & 2,5 & $526,305^{*}$ \\
\hline $\mathrm{Ne}$ & 928 & 40,6 & 16 & 0,7 & 1104 & 48,3 & 123 & 5,4 & 51 & 2,2 & 64 & 2,8 & \\
\hline \multicolumn{14}{|c|}{ kućanstvo $^{* * *}$} \\
\hline 1 & 437 & 41,6 & 5 & 0,5 & 325 & 31 & 226 & 21,5 & 15 & 1,4 & 42 & 4 & $442,871^{* *}$ \\
\hline 2 & 4190 & 60 & 80 & 1,1 & 2142 & 30,7 & 328 & 4,7 & 81 & 1,2 & 162 & 2,3 & \\
\hline \multicolumn{14}{|c|}{ obrazovni status } \\
\hline OŠ & 1859 & 61,1 & 13 & 0,4 & 615 & 20,2 & 416 & 13,7 & 41 & 1,3 & 98 & 3,2 & $555,770^{*}$ \\
\hline SŠ & 2200 & 55,7 & 54 & 1,4 & 1444 & 36,5 & 121 & 3,1 & 50 & 1,3 & 83 & 2,1 & \\
\hline VSS & 549 & 54,7 & 17 & 1,7 & 398 & 39,6 & 13 & 1,3 & 5 & 0,5 & 22 & 2,2 & \\
\hline \multicolumn{14}{|l|}{ dob } \\
\hline $18-24$ & 388 & 39,6 & 3 & 0,3 & 539 & 54,9 & 11 & 1,1 & 21 & 2,1 & 19 & 1,9 & $955,072^{*}$ \\
\hline $25-34$ & 709 & 53,3 & 16 & 1,2 & 547 & 41,2 & 23 & 1,7 & 16 & 1,2 & 18 & 1,4 & \\
\hline $35-49$ & 1320 & 59,5 & 48 & 2,2 & 691 & 31,2 & 91 & 4,1 & 21 & 0,9 & 47 & 2,1 & \\
\hline $50-64$ & 1145 & 61,4 & 15 & 0,8 & 477 & 25,6 & 147 & 7,9 & 19 & 1 & 63 & 3,4 & \\
\hline $65+$ & 1065 & 65 & 2 & 0,1 & 212 & 12,9 & 281 & 17,2 & 20 & 1,2 & 58 & 3,5 & \\
\hline \multicolumn{14}{|c|}{ visina dohotka $* * * *$} \\
\hline 1 & 837 & 52,1 & 8 & 0,5 & 370 & 23,1 & 304 & 18,9 & 26 & 1,6 & 60 & 3,7 & $523,396^{*}$ \\
\hline 2 & 1316 & 56,9 & 30 & 1,3 & 737 & 31,9 & 139 & 6 & 34 & 1,5 & 55 & 2,4 & \\
\hline 3 & 1340 & 61 & 30 & 1,4 & 711 & 32,4 & 56 & 2,6 & 22 & 1 & 36 & 1,6 & \\
\hline 4 & 1065 & 59,2 & 15 & 0,8 & 603 & 33,5 & 52 & 2,9 & 13 & 0,7 & 50 & 2,8 & \\
\hline \multicolumn{14}{|c|}{ veličina naselja ${ }^{* * * * *}$} \\
\hline 1 & 2045 & 59,7 & 45 & 1,3 & 838 & 24,5 & 362 & 10,6 & 55 & 1,6 & 80 & 2,3 & $239,726^{*}$ \\
\hline 2 & 803 & 57,8 & 14 & 1 & 449 & 32,3 & 78 & 5,6 & 13 & 0,9 & 32 & 2,3 & \\
\hline 3 & 762 & 54,3 & 18 & 1,3 & 512 & 36,5 & 63 & 4,5 & 17 & 1,2 & 31 & 2,2 & \\
\hline 4 & 1017 & 55,9 & 8 & 0,4 & 669 & 36,8 & 51 & 2,8 & 12 & 0,7 & 61 & 3,4 & \\
\hline
\end{tabular}

Napomene: za objašnjenje oznaka vidjeti Tablicu 3

Analiza percepcije izvora promatranih oblika socijalne podrške s obzirom na sociodemografska obilježja pokazala je statistički značajne razlike na svim varijablama (Tablice 3-5). Kod savjetodavne i emocionalne podrške dominiraju slični obrasci ponašanja s obzirom na sociodemografska obilježja ispitanika. U slučaju potrebe za savjetodavnom ili emocionalnom podrškom (Tablice 3,4), žene, osobe s djecom, nižega obrazovnog statusa, starije životne dobi te iz manjih sredina primarnim izvorom podrške percipiraju obitelj / partnera i susjede. Osobe iz višečlanih obitelji usmjerenije su na obitelj / partnera, a samci na susjede. Nadalje, dok se osobe višega dohotka češće obraćaju članu obitelji / partneru, osobe nižega dohodovnog statusa češće će se obratiti susjedu. S druge strane, mu- 
DRUŠ. ISTRAŽ. ZAGREB GOD. 21 (2012), BR. 1 (115) STR. 39-58

DOBROTIĆ, I. LAKLIJA, M.
OBRASCI... škarci, osobe bez partnera i djece, višega obrazovnog i dohodovnoga statusa, mlađe dobi i iz većih sredina važnim izvorom savjetodavne te emocionalne podrške učestalije percipiraju prijatelje.

Rezultati potvrđuju ranija istraživanja koja pokazuju kako usmjerenost na podršku obitelji raste s dobi pojedinca (Kearns i Forrest, 2000.) te da starije osobe učestalije razmjenjuju podršku sa susjedima (Perren i sur., 2004.). To potvrđuje važnost lokalnih veza za starije osobe te važnost susjeda kao izvora socijalne integracije i podrške, što može biti važno u situacijama kada su postojeće socijalne veze nagrizene smrću, migracijama, manjom mobilnošću, a starenje povezano s narušenim zdravljem te smanjenjem drugih resursa pojedinca, što naglašavaju Perren i sur. (2004.). Činjenicu da se osobe višega dohodovnog statusa rjeđe obraćaju susjedima za podršku Perren i sur. (2004.) objašnjavaju time da oni raspolažu s manje praktičnih vještina te vremenskih i drugih resursa za preuzimanje svakodnevnih zadataka i nisu skloni uspostavljati potporne mreže sa susjedima, nego se služe uslugama tržišta. Analiza pokazuje veću sklonost žena traženju podrške od obitelji i susjeda, dok kod muškaraca više dominiraju prijatelji. Rezultati idu u prilog tezi Moorea (1990.) kako su žene sklonije uključivati rođake i susjede kada se radi o osobnim pitanjima, dok su muškarci skloniji nesrodničkim vezama u tom pogledu.

Kod percepcije izvora financijske podrške (Tablica 5) obrazac je ponašanja nešto drugačiji. Dok kod savjetodavne i emocionalne podrške obitelj i susjede primarnim izvorom podrške percipiraju osobe sličnih sociodemografskih obilježja, rezultati za financijsku podršku su drugačiji. Osobe višega obrazovnog i dohodovnoga statusa, mlađe dobi te iz većih sredina učestalije izvorom financijske podrške percipiraju člana obitelji / partnera, dok osobe nižega obrazovnog i dohodovnog statusa, starije dobi te iz manjih naselja učestalije izdvajaju susjede. Glede osoba koje prijatelje percipiraju kao važan izvor financijske podrške situacija je slična onoj kod emocionalne te savjetodavne podrške; pa ih izvorom podrške češće percipiraju muškarci, osobe višega obrazovnog i dohodovnoga statusa, mlađe životne dobi te iz većih sredina. Potreba financijske podrške pokazala se situacijom u kojoj se ispitanici najčešće nemaju komu obratiti, gdje su se ranjivijima pokazale osobe nižega obrazovnog i dohodovnoga statusa, starije dobi te iz samačkih kućanstava i manje sredine.

Rezultati potvrđuju nalaze o neadekvatnoj potpornoj mreži osoba skromnijih ekonomskih resursa (Novak i sur., 2004.) te nižeg obrazovanja (Fischer, 1982.; Wall i sur., 2001.) i starije životne dobi (Fischer, 1982.; Saraceno i sur., 2005.). Nalazi idu u prilog tezi Paugama i Russella (2000.) kako je dob važan čimbenik kod financijske podrške od strane obitelji te je vjerojat- 
nije da mlađe osobe primaju pomoć od obitelji, što je rezultat progresivnoga smanjenja broja starijih rođaka tijekom životnoga ciklusa, ali i socijalnih navika pomaganja mladima. Rezultat da se osobe nižeg obrazovanja češće nemaju komu obratiti u potrebi za financijskom podrškom Saraceno i sur. (2005.)

(1) TABLICA 5 pripisuju učinku društvenoga položaja, pa je za obrazovanije Percepcija izvora financijske podrške osobe vjerojatnije da će pripadati višim socijalnim slojevima gdje su financijski resursi dostupniji.

\begin{tabular}{|c|c|c|c|c|c|c|c|c|c|c|c|c|c|}
\hline \multirow[b]{2}{*}{ Prediktori } & \multicolumn{2}{|c|}{$\begin{array}{r}\text { Član obitelji / } \\
\text { partner }\end{array}$} & \multicolumn{2}{|c|}{$\begin{array}{l}\text { Kolega } \\
\text { s posla } \\
\end{array}$} & \multicolumn{2}{|c|}{ Prijatelj } & \multicolumn{2}{|c|}{ Susjed } & \multicolumn{2}{|c|}{ Drugi } & \multicolumn{2}{|c|}{ Nitko } & \multirow[b]{2}{*}{$\chi^{2}$} \\
\hline & $\mathrm{N}$ & $\overline{\%}$ & $\bar{N}$ & $\%$ & $\mathrm{~N}$ & 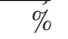 & $\mathrm{N}$ & $\%$ & $\mathrm{~N}$ & $\%$ & $\mathrm{~N}$ & $\%$ & \\
\hline \multicolumn{14}{|l|}{ spol } \\
\hline M & 1789 & 48,4 & 89 & 2,4 & 970 & 26,3 & 115 & 3,1 & 215 & 5,8 & 517 & 14 & \multirow[t]{2}{*}{$188,703^{*}$} \\
\hline$\check{Z}$ & 2436 & 61,1 & 38 & 0,9 & 655 & 15,8 & 135 & 3,3 & 220 & 5,3 & 565 & 13,6 & \\
\hline \multicolumn{14}{|c|}{ partnerski status } \\
\hline $\mathrm{Da}$ & 2634 & 55 & 80 & 1,7 & 1016 & 21,2 & 157 & 3,3 & 311 & 6,5 & 592 & 12,4 & \multirow[t]{2}{*}{$38,122^{*}$} \\
\hline $\mathrm{Ne}$ & 1684 & 55,6 & 45 & 1,5 & 605 & 20 & 90 & 3 & 125 & 4,1 & 482 & 15,9 & \\
\hline \multicolumn{14}{|c|}{ prisutnost djece } \\
\hline $\mathrm{Da}$ & 3104 & 55,2 & 88 & 1,6 & 1122 & 20 & 187 & 3,3 & 337 & 6 & 785 & 14 & \multirow[t]{2}{*}{$14,719^{* *}$} \\
\hline $\mathrm{Ne}$ & 1221 & 55 & 39 & 1,8 & 503 & 22,6 & 63 & 2,8 & 98 & 4,4 & 297 & 13,4 & \\
\hline \multicolumn{14}{|c|}{ kućanstvo ${ }^{* * *}$} \\
\hline 1 & 507 & 49,1 & 8 & 0,8 & 205 & 19,9 & 45 & 4,4 & 29 & 2,8 & 238 & 23,1 & \multirow[t]{2}{*}{$108,267^{* *}$} \\
\hline 2 & 3818 & 56,1 & 118 & 1,7 & 1420 & 20,8 & 205 & 3,0 & 406 & 6 & 844 & 12,4 & \\
\hline \multicolumn{14}{|c|}{ obrazovni status } \\
\hline OŠ & 1582 & 53,7 & 17 & 0,6 & 400 & 13,6 & 139 & 4,7 & 183 & 6,2 & 626 & 21,2 & \multirow[t]{3}{*}{$406,503^{*}$} \\
\hline SŠ & 2137 & 55,2 & 84 & 2,2 & 959 & 24,8 & 101 & 2,6 & 200 & 5,2 & 387 & 10 & \\
\hline VSS & 589 & 59,2 & 25 & 2,5 & 262 & 26,3 & 7 & 0,7 & 52 & 5,2 & 60 & 6 & \\
\hline \multicolumn{14}{|l|}{ dob } \\
\hline $18-24$ & 666 & 69,9 & 20 & 2,1 & 158 & 16,6 & 14 & 1,5 & 20 & 2,1 & 75 & 7,9 & \multirow[t]{5}{*}{$619,232^{*}$} \\
\hline $25-34$ & 743 & 57,2 & 31 & 2,4 & 323 & 24,9 & 34 & 2,6 & 75 & 5,8 & 93 & 7,2 & \\
\hline $35-49$ & 1024 & 47,2 & 54 & 2,5 & 628 & 29 & 56 & 2,6 & 183 & 8,4 & 225 & 10,4 & \\
\hline $50-64$ & 922 & 50,8 & 19 & 1 & 380 & 20,9 & 76 & 4,2 & 103 & 5,7 & 314 & 17,3 & \\
\hline $65+$ & 970 & 60,3 & 2 & 0,1 & 137 & 8,5 & 70 & 4,4 & 56 & 3,5 & 374 & 23,2 & \\
\hline \multicolumn{14}{|c|}{ visina dohotka**** } \\
\hline 1 & 688 & 44,1 & 17 & 1,1 & 222 & 14,2 & 119 & 7,6 & 81 & 5,2 & 434 & 27,8 & \multirow[t]{4}{*}{$656,343^{*}$} \\
\hline 2 & 1165 & 51,7 & 40 & 1,8 & 476 & 21,1 & 72 & 3,2 & 136 & 6 & 366 & 16,2 & \\
\hline 3 & 1253 & 58,1 & 48 & 2,2 & 511 & 23,7 & 39 & 1,8 & 156 & 7,2 & 148 & 6,9 & \\
\hline 4 & 1148 & 65,6 & 20 & 1,1 & 382 & 21,8 & 17 & 1 & 59 & 3,4 & 123 & 7 & \\
\hline \multicolumn{14}{|c|}{ veličina naselja***** } \\
\hline 1 & 1817 & 54,1 & 57 & 1,7 & 576 & 17,1 & 152 & 4,5 & 197 & 5,9 & 562 & 16,7 & \multirow[t]{4}{*}{$151,902^{*}$} \\
\hline 2 & 745 & 55,5 & 27 & 2 & 305 & 22,7 & 28 & 2,1 & 57 & 4,2 & 180 & 13,4 & \\
\hline 3 & 778 & 56,8 & 28 & 2 & 285 & 20,8 & 29 & 2,1 & 67 & 4,9 & 182 & 13,3 & \\
\hline 4 & 985 & 55,6 & 14 & 0,8 & 459 & 25,9 & 41 & 2,3 & 115 & 6,5 & 158 & 8,9 & \\
\hline
\end{tabular}

Napomene: za objašnjenje oznaka vidjeti Tablicu 3

Analiza pokazuje zanimljive rezultate usmjerimo li se na osobe koje se percipiraju izvorom podrške. Naime, prijateljima i susjedima obraćaju se osobe suprotnih sociodemografskih karakteristika. Dok prijatelje važnim izvorom podrške percipiraju muškarci, osobe višega obrazovnog i dohodovnoga statusa, mlađe životne dobi te iz veće sredine, na susjeda kao važan izvor podrške gledaju žene, osobe nižega obrazovnog i dohodovnoga statusa, starije životne dobi te iz manje sredine. 
To ponajprije ukazuje na razvijenije susjedske odnose u manjim sredinama te kod osoba nižega socioekonomskog statusa, dok se društvenost osoba u većim sredinama te pozitivnijih socioekonomskih obilježja više zasniva na prijateljskim mrežama.

\section{ZAKLJUČNA RAZMATRANJA}

Analiza pokazuje učestalost socijalnih interakcija unutar sekundarne sfere društvenosti i učinkovitost socijalnih veza, pri čemu je primarni izvor neformalne socijalne podrške obitelj. Usporedimo li rezultate s ranijim istraživanjima (npr. Bohnke, 2008.; Pichler i Wallace, 2007.), Hrvatsku, kao i mediteranske te istočnoeuropske zemlje, karakterizira usmjerenost na neformalni socijalni kapital, posebice neformalne potporne mreže. Primarna usmjerenost na obitelj kao izvor socijalne podrške nosi prednosti, ali i nedostatke, na što upozoravaju Wall i sur. (2001.) ističući kako su pojedinci koji primarno počivaju na obitelji ranjiviji u situacijama obiteljskih kriza (npr. sukob, smrt, nedostatak resursa ...) i prostorne odvojenosti.

Obrasci društvenosti i percepcija izvora neformalne socijalne podrške razlikuje se s obzirom na sociodemografska obilježja ispitanika. To potvrđuje tezu Sarason i Sarasona (2009.) o postojanju individualnih razlika u mogućnosti formiranja socijalnih veza te ostvarivanja pogodnosti unutar njih. Posebno ranjivima izdvojile su se osobe starije životne dobi, nižega obrazovnog i dohodovnoga statusa te iz samačkih kućanstava, koje iskazuju manju učestalost kontakata te učestalije percipiraju da se $u$ potrebi za podrškom, osobito financijskom, nemaju komu obratiti.

Rezultati ističu važnost poznavanja obrazaca društvenosti te mehanizama zadovoljavanja potreba, posebice s aspekta kreiranja javnih politika. To je posebice važno povežemo li rezultate s tvrdnjom Sarason i Sarasona (2009.) kako socijalna izolacija te nedostatak podrške pokazuju dugotrajnost i stabilnost te ih vide rizičnim čimbenikom. Naime, kako bi programi i intervencije bili uspješniji, važno ih je temeljiti na procjeni stanja, odnosno voditi računa i o postojećim resursima i o skupinama kojima je pristup tim resursima ograničen.

Rezultati naglašavaju važnost susjedske podrške, posebice kod starijih osoba te osoba nižega socioekonomskog statusa. To upućuje na potrebu razvijanja susjedstva kao izvora socijalne podrške, što tvrdi Žganec (1995.), ističući kako je to korisno ponajprije s ekonomskog aspekta, ali i s aspekta kvalitete života. Nadalje, Perren i sur. (2004.) navode kako je promoviranje susjedske interakcije važno jer pridonosi većoj socijalnoj integraciji, posebice skupina u riziku. 
DRUŠ. ISTRAŽ. ZAGREB GOD. 21 (2012) BR. 1 (115),

STR. 39-58

DOBROTIĆ, I., LAKLIJA, M.: OBRASCI..

\section{BILJEŠKE}

LITERATURA
Kao što je istaknuto $\mathrm{u}$ uvodnom djelu, socijalne veze predstavljaju široki koncept koji zahvaća niz aspekata. Ovaj rad zahvaća tek dio te kompleksnosti, dajući preliminarni uvid u prirodu i učinkovitost socijalnih veza. Nadalje, radi se o istraživanju u kojem je mjerenje provedeno u samo jednoj vremenskoj točki, pa su interpretirani rezultati ograničena dosega, što ističu i Antonucci i sur. (2002.). Također, upitnik je uključivao tek nekoliko čestica koje su procjenjivale obrasce društvenosti i kvalitetu socijalnih veza. Kao što tvrde Paugam i Russell (2000.), takva pitanja nisu dovoljna za proučavanje prirode socijalnih veza, ali mogu upućivati na opće stanje, pa ih ubuduće treba potkrijepiti daljnjim istraživanjima, posebice kvalitativnima. Zanimljiva bi bila i istraživanja koja bi dala detaljniji uvid u dostupnost i kvalitetu formalne podrške.

1 Reher (2004.) naglašava kako je potrebno razmotriti obiteljske veze pri dizajniranju socijalnih politika, dok Perren i sur. (2004.) važnim izvorom podrške vide susjede, posebice za starije osobe, što može smanjiti potrebu za dodatnim uslugama.

2 Reher (2004.) tvrdi da je u sjevernim društvima naglasak i na javnim/ privatnim institucijama.

${ }^{3}$ U novije se vrijeme kao zasebne kategorije spominju mrežna podrška, koja stvara osjećaj pripadanja skupini s kojom dijelimo slične običaje, interese i aktivnosti (Sarafino, 2002.) te procjenjujuća podrška, kojoj je cilj pomoći osobi da unaprijedi vlastito razumijevanje stresne situacije te mobilizira postojeće resurse i pokrene strategije suočavanja (Taylor i sur., 2003.).

${ }^{4}$ Ispitanici koji su odgovorili da nemaju dijete ili roditelja izvan kućanstva nisu uključivani $\mathrm{u}$ analizu na tim česticama.

5 Tako u zemljama EU15 17\% ispitanika sudjeluje u radu dobrovoljnih organizacija, dok u zemljama EU10 9\% (Saraceno i sur., 2005.).

6 Učestalim kontaktima smatraju se oni koji se ostvaruju najmanje jednom u tjednu.

Agneessens, F., Waege, H. i Lievens, J. (2002.), Social Support Typologies: Different Approaches for Reducing Social Support Data. Metodološki zvezki, 18: 73-94.

Agneessens, F., Waege, H. i Lievens, J. (2006.), Diversity in Social Support by Role Relations: A Typology. Social Networks, 28 (4): 427-441. doi:10.1016/j.socnet.2005.10.001

Albeck, S. i Kaydar, D. (2002.), Divorced Mothers: Their Network of Friends Pre- and Post-Divorce. Journal of Divorce and Remarriage, 36 (3-4): 111-138. doi:10.1300/J087v36n03_07

Antonucci, T. C. (1985.), Personal Characteristics, Social Support, and Social Behaviour. U: R. H. Binstock i E. Shanas (ur.), Handbook of Aging and the Social Sciences (str. 94-128), New York, Van Nostrand Reinhold Company. 
DRUŠ. ISTRAŽ. ZAGREB GOD. 21 (2012), BR. 1 (115) STR. 39-58

DOBROTIĆ, I., LAKLIJA, M.: OBRASCI..
Antonucci, T. C. (2001.), Social Relations an Examination of Social Networks Social Support and Sense of Control. U: J. E. Birren i K. W. Schaie (ur.), Handbook of the Psychology of Aging (str. 427-453), San Diego, Academic Press.

Antonucci, T. C., Lansford, J. E., Akiyama, H., Smith, J., Baltes, M. M., Takahashi, K., Fuhrer, R. i Dartigues, J. (2002.), Differences between Men and Women in Social Relations, Resource Deficits, and Depressive Symptomatology During Later Life in Four Nations. Journal of Social Issues, 58 (4): 767-783. doi:10.1111/1540-4560.00289

Böhnke, P. (2008.), Are the Poor Socially Integrated? The Link between Poverty and Social Support in Different Welfare Regimes. Journal of European Social Policy, 18 (2): 133-150.

Brissette, I., Cohen, S. i Seeman, T. E. (2000.), Measuring Social Integration and Social Networks. U: S. Cohen, L. Underwood i B. Gottlieb (ur.), Support Measurements and Interventions: A Guide for Social and Health Scientists (str. 53-85), New York, Oxford Press.

Brownell, A. i Shumaker, S. A. (1985.), Where Do We Go from Here? The Policy Implications of Social Support. Journal of Social Issues, 41 (1): 111-121. doi:10.1111/j.1540-4560.1985.tb01119.x

Cobb, S. (1976.), Social Support as a Moderator of Life Stress. Psychosomatic Medicine, 38 (5): 300-314.

Demo, D. H. i Fine, M. A. (2010.), Beyond the Average Divorce, Thousand Oaks, Sage.

Fischer, C. S. (1982.), To Dwell among Friends: Personal Networks in Town and City: Personal Networks in Town and City, Chicago, University of Chicago Press.

Granovetter, M. (1983.), The Strength of Weak Ties: A Network Theory Revisited. Sociological Theory, 1: 201-233. doi:10.2307/202051

Hlebec, V. i Kogovšek, T. (2003.), Konceptualizacija socialne opore. Družboslovne razprave, 19 (43): 103-125.

Kearns, A. i Forrest, R. (2000.), Social Cohesion and Multilevel Urban Governance. Urban Studies, 37 (5-6): 995-1017. doi:10.1080/004209800 50011208

Koropeckyj-Cox, T. (1998.), Loneliness and Depression in Middle and Old Age: Are the Childless More Vulnerable? The Journal of Gerontology, 53B (6): S303-S312. doi:10.1093/geronb/53B.6.S303

Kregar, K. (2004.), Socijalna podrška djece smještene u dječjim domovima i udomiteljskim obiteljima u Republici Hrvatskoj. Ljetopis socijalnog rada, 11 (2): 229-248.

Lakey, B. i Cohen, S. (2000.), Social Support Theory and Measurement. U: S. Cohen, L. Underwood i B. Gottlieb (ur.), Support Measurements and Interventions: A Guide for Social and Health Scientists (str. 29-51), New York, Oxford Press.

Leutar, Z., Štambuk, A. i Rusac, S. (2007.), Socijalna politika i kvaliteta života starijih osoba s tjelesnim invaliditetom. Revija za socijalnu politiku, 14 (3-4): 327-346. doi:10.3935/rsp.v14i3.689

Leutar, Z., Ogresta, J. i Milić Babić, M. (2008.), Obitelji osoba s invaliditetom i mreže podrške, Zagreb, Pravni fakultet. 
DRUŠ. ISTRAŽ. ZAGREB GOD. 21 (2012) BR. 1 (115)

STR. 39-58

DOBROTIĆ, I., LAKLIJA, M.: OBRASĆL.
Lin, N. (2001.), Social Capital: A Theory of Social Structure and Action, Cambridge, Cambridge University Press.

Lin, N., Fu, Y. i Hsung, R. (2001.), The Position Generator: Measurement Techniques for Investigations of Social Capital. U: N. Lin, K. Cook i R. Burt (ur.), Social Capital: Theory and Research, New York, Aldine de Gruyter.

Mandič, S. i Hlebec, V. (2005.), Socialno omrežje kot okvir upravljanja s kakovostjo življenja in sprmemebe v Sloveniji med letoma 1987 in 2002. Družboslovne razprave, XXI (49/50): 263-285.

Matković, T. (2006.), Koliko isključeni? Sociodemografski profil, zapošljivost i socijalni kapital siromašnih radnika i kućanstava bez zaposlenih u Hrvatskoj. Revija za socijalnu politiku, 13 (3-4): 271-291. doi:10.3935/rsp.v13i3.437

Moore, G. (1990.), Structural Determinants of Men's and Women's Personal Networks. American Sociological Review, 55 (5): 726-735. doi:10.2307/2095868

Novak, M., Černigoj-Sadar, N., Dragoš, S., Dremelj, P., Ferlogoj, A., Hlebec, V., Kogovšek, T. i Nagode, M. (2004.), Omrežja socialne opore prebivalstva Slovenije, Ljubljana, Inštitut Republike Slovenije za socijalno varstvo.

Olagnero, M., Meo, A. i Corcoran, M. P. (2005.), Social Support Networks in Impoverished European Neighbourhoods. European Societies, 7 (1): 53-79. doi:10.1080/1461669042000327027

Pahl, R. i Spencer, L. (1997.), The Politics of Friendship. Renewal, 5 (34): 100-107.

Paugam, S. i Russell, H. (2000.), The Effects of Employment Precarity and Unemployment on Social Isolation. U: D. Gallie i S. Paugam (ur.), Welfare Regimes and the Experience of Unemployment in Europe (str. 243-265), Oxford, Oxford University Press.

Perren, K., Arber, S. i Davidson, K. (2004.), Neighbouring in Later Life: The Influence of Socio-Economic Resources, Gender and Household Composition on Neighbourly Relationships. Sociology, 38 (5): 965-984. doi:10.1177/0038038504047181

Petz, B., Furlan, I., Kljajić, S., Kolesarić, V., Krizmanić, M., Szabo, S. i Šverko, B. (1992.), Psihologijski rječnik, Zagreb, Prosvjeta.

Pichler, F. i Wallace, C. (2007.), Patterns of Formal and Informal Social Capital in Europe. European Sociological Review, 23 (4): 423-435. doi:10. 1093/esr/jcm013

Pichler, F. i Wallace, C. (2009.), Social Capital and Social Class in Europe: The Role of Social Networks in Social Stratification. European Sociological Review, 25 (3): 319-332. doi:10.1093/esr/jcn050

Piselli, F. (2007.), Communities, Places, and Social Networks. American Behavioral Scientist, 50 (7): 867-878. doi:10.1177/0002764206298312

Podgorelec, S. i Klempić, S. (2007.), Starenje i neformalna skrb o starim osobama u Hrvatskoj. Migracijske i etničke teme, 23 (1-2): 111-134.

Raboteg-Šarić, Z. i Pećnik, N. (2006.), Bračni status, financijske teškoće i socijalna podrška kao odrednice roditeljske depresivnosti i odgojnih postupaka. Društvena istraživanja, 15 (6): 961-1004. 
DRUŠ. ISTRAŽ. ZAGREB GOD. 21 (2012), BR. 1 (115) STR. 39-58

DOBROTIĆ, I., LAKLIJA, M. OBRASCI..
Reher, D. S. (2004.), Family Ties in Western Europe. U: G. D. Zuanna i G. A. Micheli (ur.), Strong Family and Low Fertility: A Paradox? (str. 45-76), New York, Kluwer Academic Publishers.

Saraceno, C., Olagnero, M. i Torrioni, P. (2005.), First European Quality of Life Survey: Families, Work and Social Networks, Luxembourg, Office for Official Publications of the European Communities.

Sarafino, E. P. (2002.), Health Psychology: Biopsychosocial Interactions, New York, John Wiley\&Sons.

Sarason, I. G. i Sarason, B. R. (2009.), Social Support: Mapping the Construct. Journal of Social and Personal Relationships, 26 (1): 113-120. doi:10.1177/0265407509105526

Schweizer, T., Schnegg, M. i Berzborn, S. (1998.), Personal Networks and Social Support in a Multiethnic Community of Southern California. Social Networks, 20 (1): 1-21. doi:10.1016/S0378-8733(96)00304-8

Sladović Franz, B. i Mujkanović, Đ. (2003.), Percepcija socijalne podrške djeci u dječjim domovima i u udomiteljskim obiteljima. Ljetopis socijalnog rada, 10 (2): 161-170.

Speer, P. W., Jackson, C. B. i Peterson, N. A. (2001.), The Relationship between Social Cohesion and Empowerment: Support and New Implications for Theory. Health Education E Behavior, 28 (6): 716-732. doi:10.1177/109019810102800605

Sugisawa, H., Shibata, H., Hougham, G. W., Sugihara, Y. i Liang, J. (2002.), The Impact of Social Ties on Depressive Symptoms in U.S. and Japanese Elderly. Journal of Social Issues, 58 (4): 785-804. doi:10.1111/ $1540-4560.00290$

Taylor, S. E., Klein, L. C., Gruenewald, T. L., Gurung, R. A. R. i Fernandes-Taylor, S. (2003.), Affiliation, Social Support, and Biobehavioral Responses to Stress. U: J. Suls i K. Wallston (ur.), Social Psychological Foundations of Health and Illness (str. 314-331), Malden, Blackwell Publishing.

Thoits, P. A. (1982.), Conceptual, Methodological, and Theoretical Problems in Studying Social Support as a Buffer Against Life Stress. Journal of Health and Social Behavior, 23 (2): 145-159. doi:10.2307/2136511

UNDP (2007.), Kvaliteta života u Hrvatskoj: regionalne nejednakosti, Zagreb, UNDP Hrvatska.

Vaux, A. (1985.), Variations in Social Support Associated with Gender, Ethnicity, and Age. Journal of Social Issues, 41 (1): 89-110. doi:10. 1111/j.1540-4560.1985.tb01118.x

Walen, H. R. i Lachman, M. E. (2000.), Social Support and Strain from Partner, Family and Friends: Costs and Benefits for Men and Women in Adulthood. Journal of Social and Personal Relationships, 17 (1): 5-30. doi:10.1177/0265407500171001

Wall, K., Aboim, S., Cunha, V. i Vasconcelos, P. (2001.), Families and Informal Support Networks in Portugal: The Reproduction of Inequality. Journal of European Social Policy, 11 (3): 213-233. doi:10.1177/0958928 70101100302

Wellman, B. i Wortley, S. (1989.), Brothers' Keepers: Situating Kinship Relations in Broader Networks of Social Support. Sociological Perspectives, 32 (3): 273-306. 
DRUŠ. ISTRAŽ. ZAGREB GOD. 21 (2012) BR. 1 (115),

STR. 39-58

DOBROTIĆ, I., LAKLIJA, M OBRASCI..
Wethington, E. i Kessler, R. C. (1986.), Perceived Support, Received Support, and Adjustment to Stressful Life Events. Journal of Health and Social Behavior, 27 (1): 78-89. doi:10.2307/2136504

Žganec, N. (1995.), Obitelj - socijalna mreža - socijalni rad. Društvena istraživanja, 4 (4-5): 503-515.

\section{Patterns of Sociability and Perception of Informal Social Support in Croatia}

Ivana DOBROTIĆ, Maja LAKLIJA

Faculty of Law, Zagreb

This paper provides insight into the nature of social ties and perceptions of sources of informal social support in Croatia with regard to socio-demographic characteristics of respondents. The source of data was the European Quality of Life Survey, which was carried out in Croatia by the UNDP Croatia. The analysis was conducted on a sample of 8114 adult respondents. Linear regression was used for the analysis of factors contributing to the frequency of contacts, while $\chi^{2}$-test was used for analysing perceptions of sources of informal social support. The results showed frequent social interactions within the secondary sphere of sociability, while the family is perceived as the primary source of informal social support. Gender, age, marriage or cohabitation, household size, settlement size and the income size have appeared as the most significant predictors of the incidence of contacts within the secondary sphere of sociability. Furthermore, while practical support is primarily based on the family, in the need for emotional and financial support, respondents are going to turn to family and friends as well. In the case of need for emotional support, neighbours are also perceived as important sources of support. While in the need for financial support, individuals most often perceived that they had no one to turn to.

Keywords: sociability, social ties, social support 